7th International Symposium on Superalloy 718 and Derivatives Edited by: E.A. Ott, J.R. Groh, A. Banik, I. Dempster, T.P. Gabb, R. Helmink, X. Liu, A. Mitchell, G.P. Sjöberg, and A. Wusatowska-Sarnek TMS (The Minerals, Metals \& Materials Society), 2010

\title{
AGING EFFECTS ON THE $\gamma^{\prime}$ AND $\gamma^{\prime \prime}$ PRECIPITATES OF INCONEL 718 SUPERALLOY
}

\author{
Hui-Yun Bor ${ }^{1}$, Chao-Nan $\mathrm{Wei}^{1}$, Huu Tri Nguyen ${ }^{2}$, An-Chou $\mathrm{Yeh}^{2}$, Chen-Ming Kuo ${ }^{2 *}$ \\ ${ }^{1}$ Materials and Electro-Optics Research Division, Chung-Shan Institute of Science and \\ Technology; P.O. Box 90008-8-4; Lungtan, Taoyuan 32599, Taiwan, ROC \\ ${ }^{2}$ Department of Mechanical and Automation Engineering, I-Shou University; \\ 1, Sec. 1, Syuecheng Rd.; Dashu, Kaoshiung, 84001, Taiwan, ROC
}

Keywords: Inconel 718, Aging effects, $\gamma^{\prime}$ precipitate, $\gamma^{\prime \prime}$ precipitate

\begin{abstract}
The excellent mechanical properties of Inconel 718 are due to the $\gamma$ and specifically the $\gamma^{\prime}$ precipitates. Solution heat treatment was performed at $1095^{\circ} \mathrm{C}$ for $1 \mathrm{~h}$ followed by air cooling. A $\delta$-phase precipitation heat treatment was made at $955^{\circ} \mathrm{C}, 1 \mathrm{~h} / \mathrm{AC}$. Finally a double-aging at 720 ${ }^{\circ} \mathrm{C}, 8 \mathrm{~h} / \mathrm{FC}$ at $57{ }^{\circ} \mathrm{C} / \mathrm{h}$ down to $620^{\circ} \mathrm{C}, 8 \mathrm{~h} / \mathrm{AC}$ to precipitate both $\gamma^{\prime}$ and $\gamma^{\prime \prime}$ phases. The precipitation of both $\gamma^{\prime}$ and $\gamma^{\prime \prime}$ phases were studied in details after aging treatment by the use of transmission electron microscopy. The spherical precipitates were identified as $\gamma^{\prime}$ phase and the ellipsoidal precipitates were $\gamma^{\prime \prime}$ phase. At $720{ }^{\circ} \mathrm{C}$ for $8 \mathrm{~h}$ both $\gamma^{\prime}$ and $\gamma^{\prime \prime}$ are growing; the mean long-axis of $\gamma^{\prime \prime}$ particle is $40 \mathrm{~nm}$ and the mean short-axis is $14 \mathrm{~nm}$ whereas the average diameter of the spherical $\gamma^{\prime}$ particle is $17 \mathrm{~nm}$. However, at $620^{\circ} \mathrm{C}, \gamma^{\prime \prime}$ stops growing but $\gamma^{\prime}$ continue to grow and the diameter increases to $21 \mathrm{~nm}$.
\end{abstract}

\section{Introduction}

The importance of the alloy Inconel 718 has been steadily growing since it was introduced more than fifty years ago due to its exceptional strength and versatility and it is today the predominant Nickel-Iron based superalloy [1,2], and represents about half the total tonnage of superalloys used throughout the world. It is made in virtually all product forms, such as forged disks, shafts supports, fasteners, sheet components and frame sections [3]. Inconel 718 is mainly strengthened by the metastable semi-coherent body centered tetragonal precipitates $\gamma^{\prime \prime}$ phase $\mathrm{Nb}_{3}(\mathrm{Al}, \mathrm{Ti})$ and the coherent face centered cubic $\gamma^{\prime}$ phase $\mathrm{Ni}_{3}(\mathrm{Al}, \mathrm{Ti})$.

Both solid solution and precipitation strengthening are the major steps in strengthening mechanisms [1-4], and the heat treatment scheme of Inconel 718 is divided into solid solution treatment and aging treatment. The standard solution treatment temperature for wrought Inconel 718 is $980{ }^{\circ} \mathrm{C}$ followed by a double-aging $720^{\circ} \mathrm{C}, 8 \mathrm{~h} / \mathrm{FC} 57{ }^{\circ} \mathrm{C} / \mathrm{h}$ to $620^{\circ} \mathrm{C}, 8 \mathrm{~h} / \mathrm{AC}[3,4]$. For wrought Inconel 718 , the solution temperature was increased to $1032{ }^{\circ} \mathrm{C}$ to improve the high temperature crack propagation resistance [5]. For cast Inconel 718, the standard homogenization heat treatment of $1095^{\circ} \mathrm{C} / 1 \mathrm{~h}$ dissolves most of the $\delta$-phase and a portion of the Laves [6]. Since niobium is the major element for the precipitation strengthening through $\gamma^{\prime}$ and $\gamma^{\prime \prime}$, a higher solution temperature will increase the niobium content and thus increase the precipitation strengthening. The same heat treatment schedule of cast material applied on wrought material

\footnotetext{
* Corresponding author. cmkuo@isu.edu.tw
} 
will ensure that optimized solution and precipitation hardening will take place although with an associated grain growth which in industrial practice usually is unacceptable.

Both the orthorhombic $\delta$-phase and carbides are generally viewed upon as deleterious, but it is well known $[7,8]$ that the $\delta$-phase is used to control the grain size in wrought processes by pinning grain boundaries. In Inconel 718, $\delta$-phase formation occurs in the $650-980{ }^{\circ} \mathrm{C}$ temperature range with platelet morphology [2].

\section{Experimental Procedure}

Round bar Inconel 718 superalloy with diameter $12.8 \mathrm{~mm}$ was used as test material produced from double melt (VIM/VAR) ingots. The chemical composition is shown in Table I.

Table I. Chemical composition of Inconel 718 in wt $\%$

\begin{tabular}{|c|c|c|c|c|c|c|c|}
\hline $\mathrm{C}$ & $\mathrm{Mn}$ & $\mathrm{Fe}$ & $\mathrm{S}$ & $\mathrm{Si}$ & $\mathrm{Cu}$ & $\mathrm{Ni}$ & $\mathrm{Cr}$ \\
\hline 0.04 & 0.09 & 18.64 & 0.0001 & 0.07 & 0.17 & $\mathrm{Bal}$ & 18.11 \\
$\mathrm{Al}$ & $\mathrm{Ti}$ & $\mathrm{Co}$ & $\mathrm{Mo}$ & $\mathrm{Nb}$ & $\mathrm{Ta}$ & $\mathrm{P}$ & $\mathrm{B}$ \\
\hline 0.53 & 0.95 & 0.21 & 3.03 & 5.05 & 0.01 & 0.009 & 0.003 \\
\hline
\end{tabular}

Inconel 718 is usually used in the solution and aged condition, the exact conditions of the temperatures, time, and cooling rates depend on the application and mechanical property needs. Many aerospace applications require high tensile and fatigue strength, as well as good stressrupture properties, so that a solution treatment below the delta-solvus and a two-step aging treatments are used [1-4].

In the present study, standard heat treatments for precipitation-strengthened cast Inconel 718 [4], were employed the solution heat treatment at $1095{ }^{\circ} \mathrm{C}$ for $1 \mathrm{~h} / \mathrm{AC}$, and then aging at $955^{\circ} \mathrm{C}, 1$ $\mathrm{h} / \mathrm{AC}$ to precipitate $\delta$-phase, then followed by a double-aging at $720^{\circ} \mathrm{C}, 8 \mathrm{~h} / \mathrm{FC} 57^{\circ} \mathrm{C} / \mathrm{h}$ to 620 ${ }^{\circ} \mathrm{C}, 8 \mathrm{~h} / \mathrm{AC}$. The heat treatment steps are schematically shown in Figure 1.

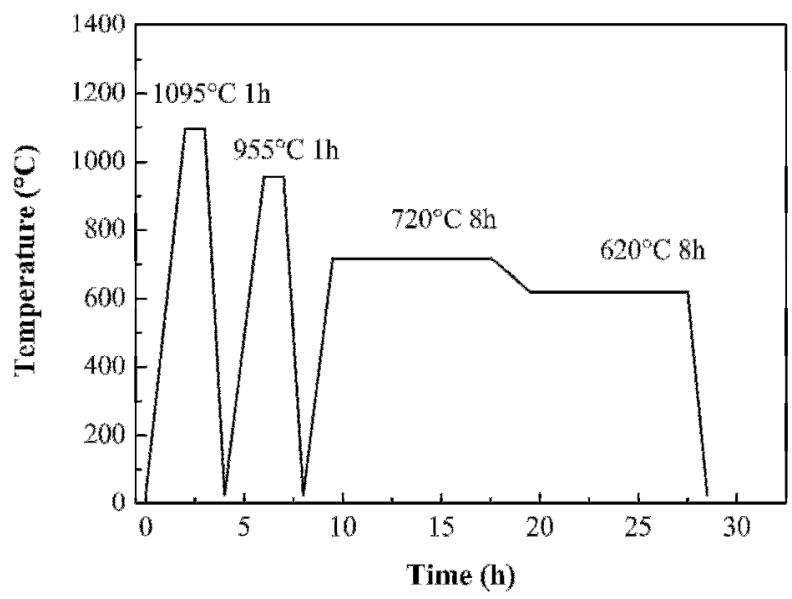


Figure 1. Heat treatment scheme of Inconel 718.

Microstructure characterization was performed with scanning electron microcopy (SEM) and transmission electron microcopy (TEM). The average size of strengthening precipitates of $\gamma^{\prime}$ and $\gamma^{\prime \prime}$ was quantitatively determined by TEM bright-field and dark-field images. Metallographic sections were prepared using standard mechanical polishing procedures and electrolytically etched in $\mathrm{HCl}: \mathrm{HNO}_{3}: \mathrm{HF}: \mathrm{H}_{2} \mathrm{O}$ solution with volume ratio of 50:10:2:38. A Hitachi-4700 FE-SEM with a Horiba EDS system was used to examine the microstructure. Twin jet electrolytic etching was employed in $90 \% \mathrm{C}_{2} \mathrm{H}_{5} \mathrm{OH}+10 \% \mathrm{HClOH}$ solution at $-20{ }^{\circ} \mathrm{C}$ and $22 \mathrm{~V}$ voltage to prepare TEM specimens, which were observed by FEI Tecnai $\mathrm{G}^{2} 20$ S-twin TEM.

\section{Results and Discussion}

SEM image of as-received Inconel 718 with an average grain size $25 \mu \mathrm{m}$ shows that globular $\delta$ phase and carbides are uniformly distributed in the matrix, as shown in Figure 2. Some of the carbides are relatively large and located at the grain boundaries, and of $\mathrm{NbC} / \mathrm{TiC}$ type verified by both SEM EDS analysis and TEM (illustrated in Figure 3) analysis. After the solution treatment at $1095{ }^{\circ} \mathrm{C}$ the grains grow since the pinning effect of the grain boundaries $\delta$-phase disappears when this phase is dissolved. A one hour heat treatment renders an average grain size of $142 \mu \mathrm{m}$ as shown in Figure 4. Comparison between the as received material (Figure 2) and the solutionized material (Figure 4 ) clearly shows that all $\delta$-phase has been dissolved while the carbides remain undissolved.

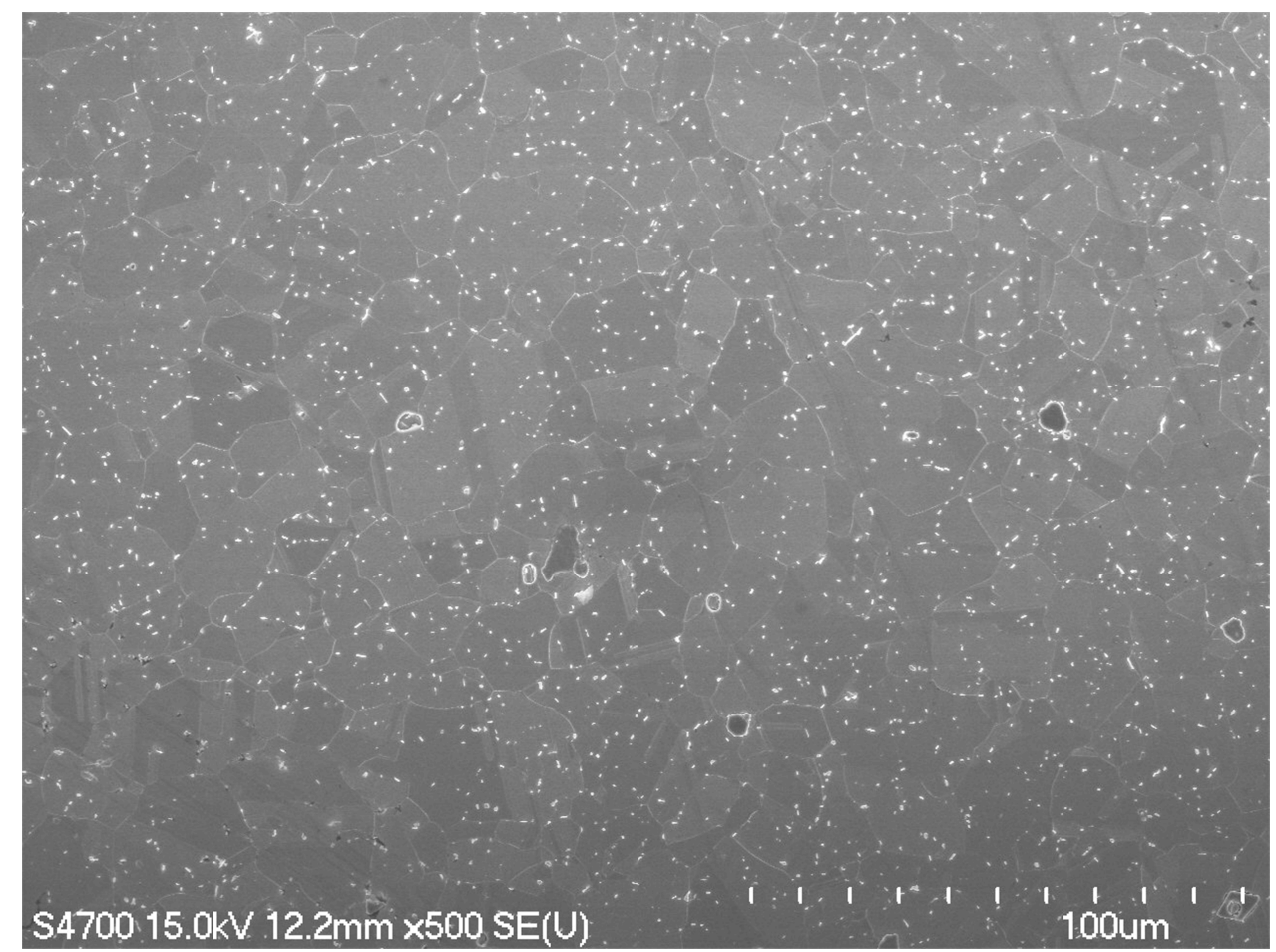

Figure 2. SEM image showing globular $\delta$-phase and carbides (the large blocky particles) of the as-received Inconel 718. 


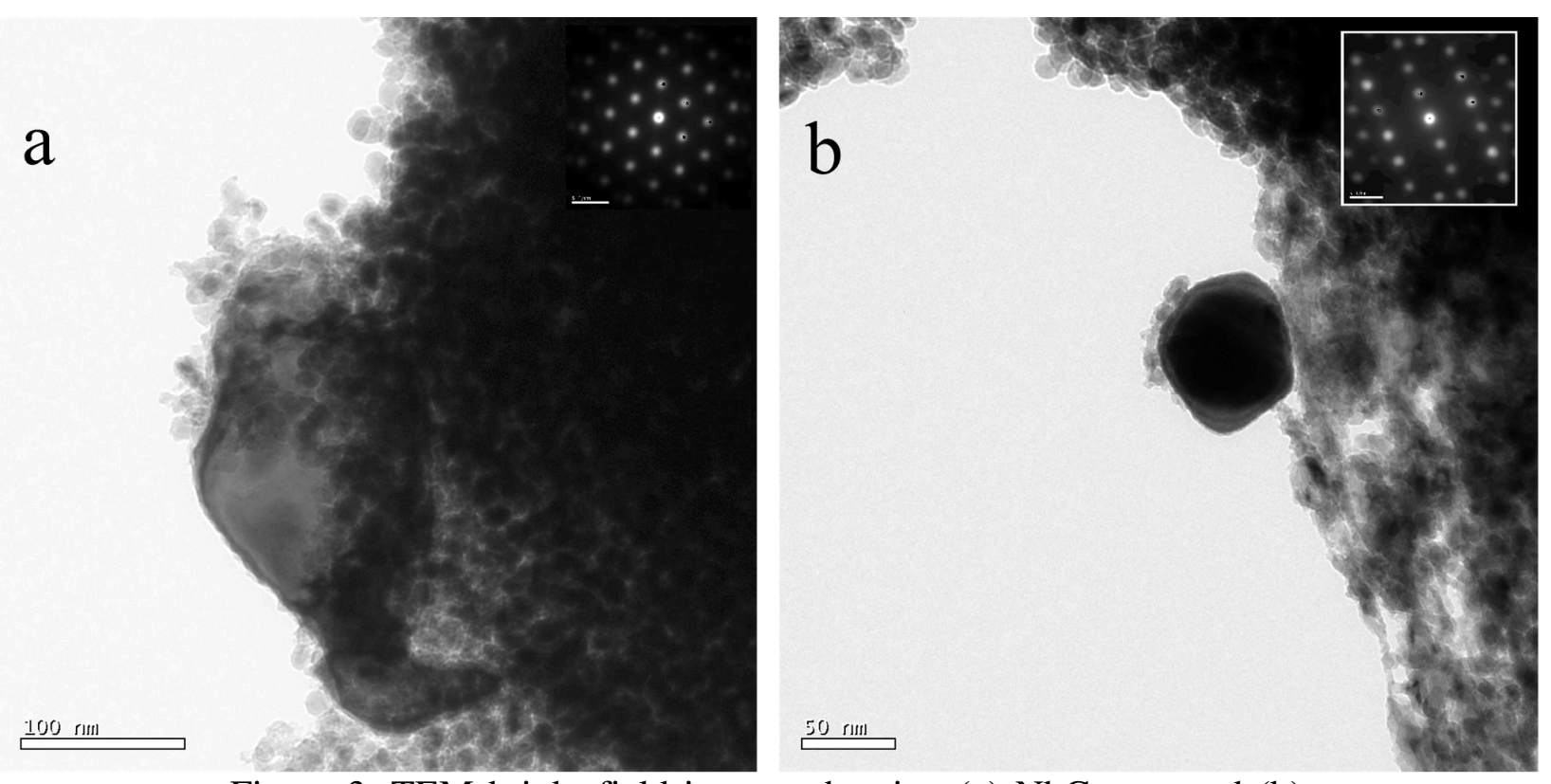

Figure 3. TEM bright field images showing (a) $\mathrm{NbC}$ type and (b) TiC type carbides of the as-received Inconel 718.

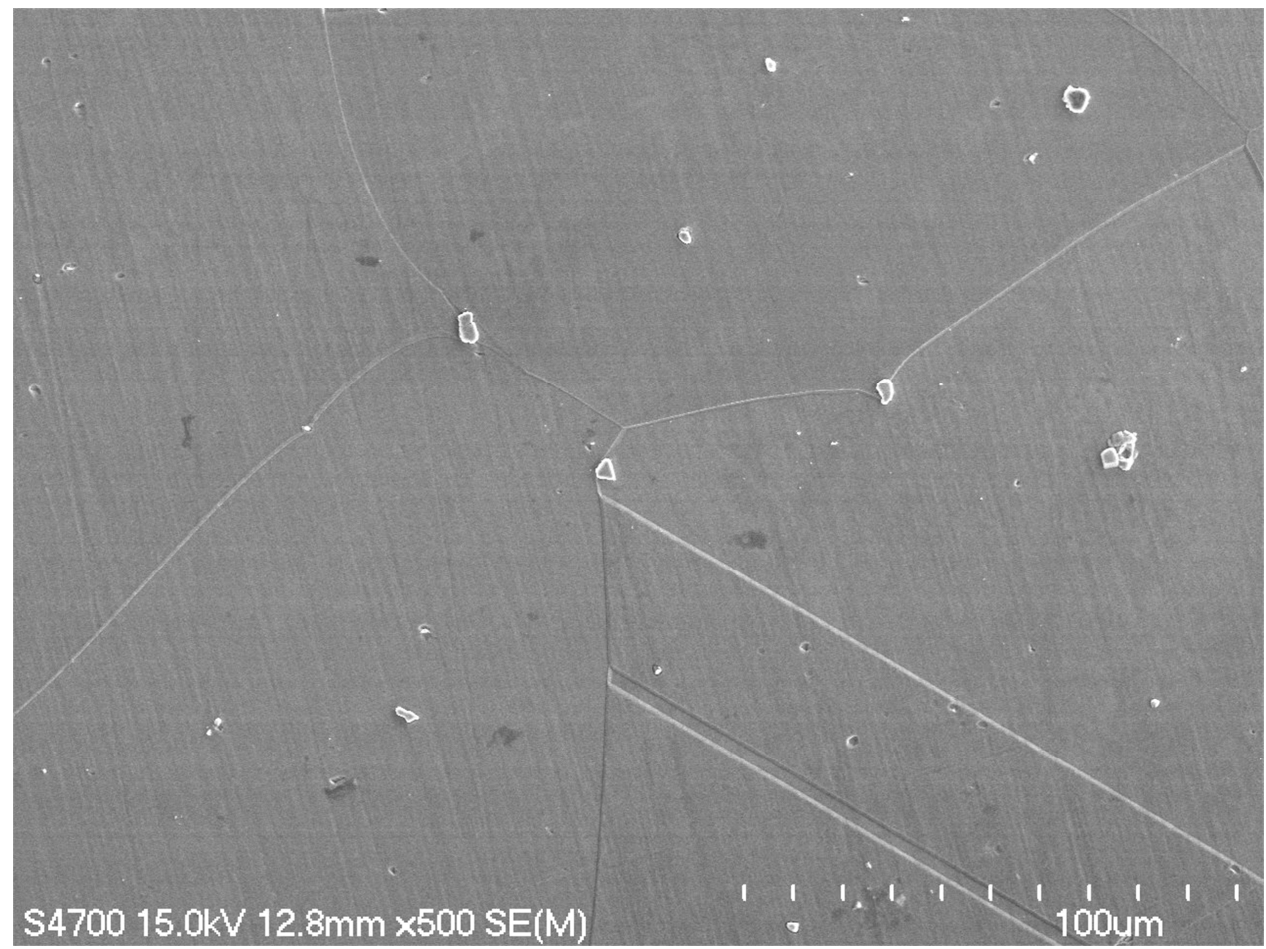

Figure 4. SEM image of Inconel 718 after solid solution treatment with carbides clearly visible and some pinning effects of grain boundaries.

The first aging treatment at $955^{\circ} \mathrm{C}$ did, as expected, not change the grain size, but also, as expected, platelet $\delta$-phase precipitated at the grain boundaries The amount of $\delta$-phase after one hour is limited [9] as shown in Figure 5. SEM EDS analysis confirms that $\mathrm{Ni}_{3} \mathrm{Nb}$ is the chemical composition of the delta phase, which is also verified by TEM diffraction pattern analysis as shown in Figure 6. 

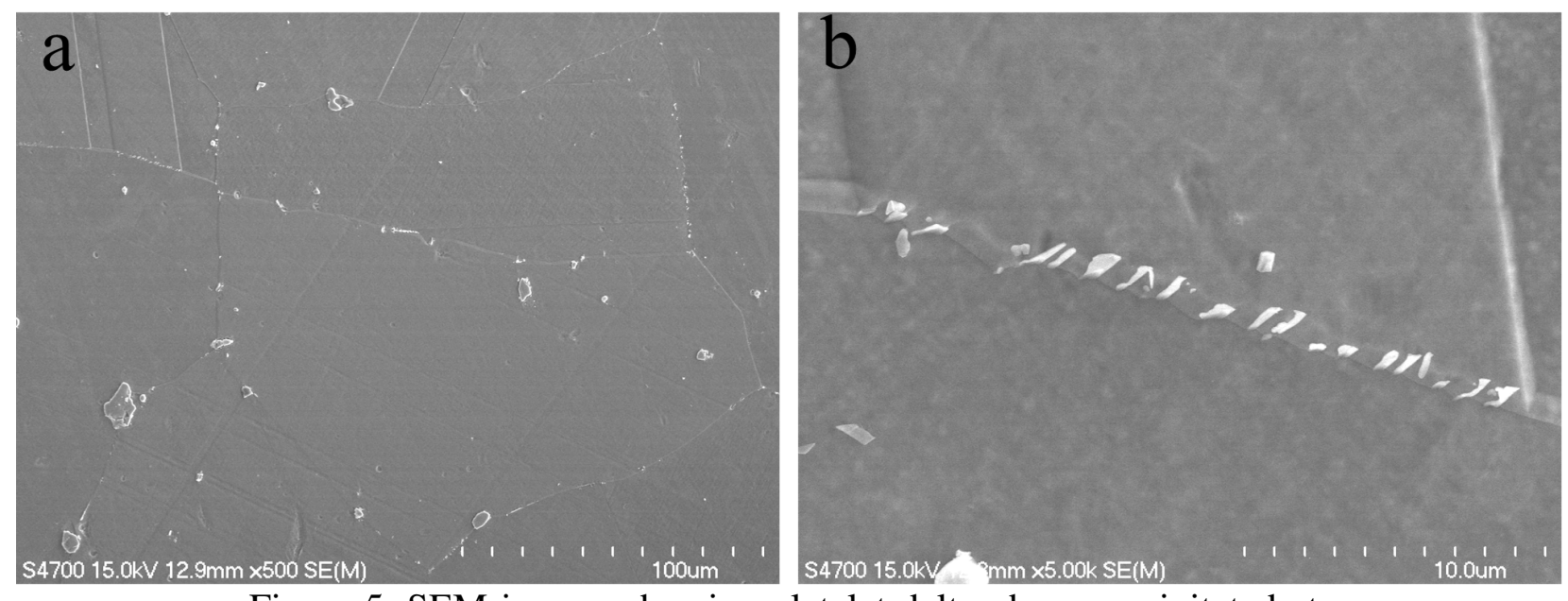

Figure 5. SEM images showing platelet delta phase precipitated at grain boundary of Inconel 718 after solid solution and aging treatments at $955^{\circ} \mathrm{C}$ for $1 \mathrm{~h}$ (a) $500 \mathrm{X}$, (b) $5,000 \mathrm{X}$.
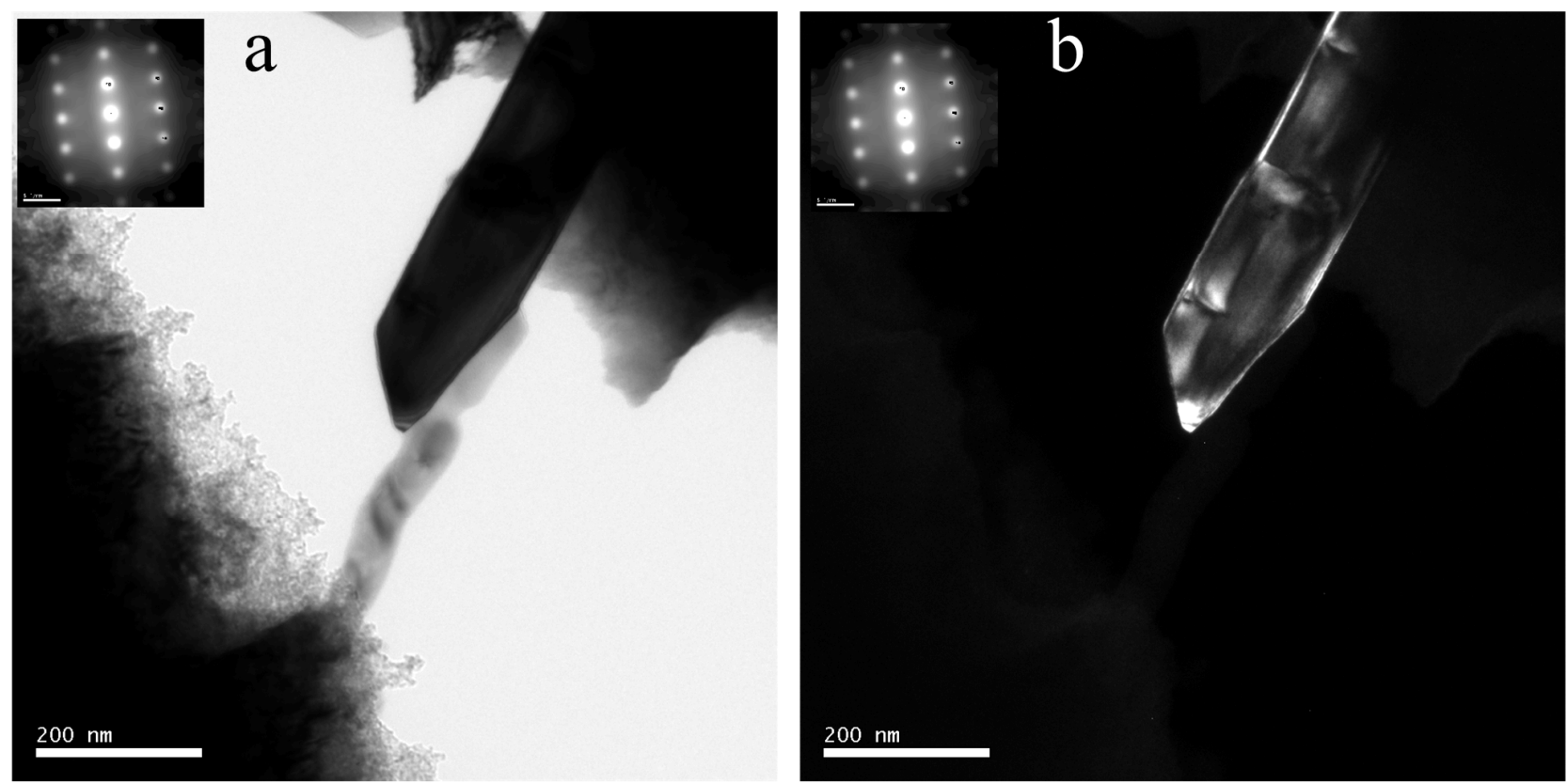

Figure 6. TEM (a) bright field and (b) dark field images confirm that the platelets at the grain boundary are the orthorhombic delta phase.

The double-aging treatment, $720{ }^{\circ} \mathrm{C}, 8 \mathrm{~h} / \mathrm{FC} 57^{\circ} \mathrm{C} / \mathrm{h}$ to $620^{\circ} \mathrm{C}, 8 \mathrm{~h} / \mathrm{AC}$ does not affect the grain size $(170 \mu \mathrm{m})$ or the amount of $\delta$-phase as seen by comparing Figure 5 with Figure 7 to the aging controls the size distribution of $\gamma^{\prime}$ and $\gamma^{\prime \prime}$ precipitates. The spherical precipitates observed inside the grains are identified as $\gamma^{\prime}$ phase and the dish shaped precipitates as $\gamma^{\prime \prime}$ phase shown in Figure 8a, the bright field TEM image. As shown in Figure 8b, the TEM dark field image reveals very little information either about the $\gamma^{\prime}$ or the $\gamma^{\prime \prime}$ precipitates. Figure 9 shows the selected-area diffraction (SAD) patterns obtained from [100] matrix zones axis. From the SAD analysis, the reciprocal lattice points must be treated as streaks parallel to the $\mathrm{z}$ direction. The diffraction pattern of [211] $\gamma^{\prime}$ and [201] $\gamma^{\prime \prime}$ zones axis can be determined by the use of diffraction pattern 
data and JCPD card. By the TEM EDS spectra analyses of $\gamma^{\prime}$ and $\gamma^{\prime \prime}$ phases shown in Figure 10, one can identify that $\gamma^{\prime}$ has a FCC structure based on $\mathrm{Ni}_{3} \mathrm{Al}$, with $\mathrm{Ti}$ and some $\mathrm{Nb}$ substituting on $\mathrm{Al}$ sites, $\gamma^{\prime \prime}$ has a BCT structure based on $\mathrm{Ni}_{3} \mathrm{Nb}$ with minor $\mathrm{Al}$ and $\mathrm{Ti}$ substituting on the $\mathrm{Nb}$ sites.

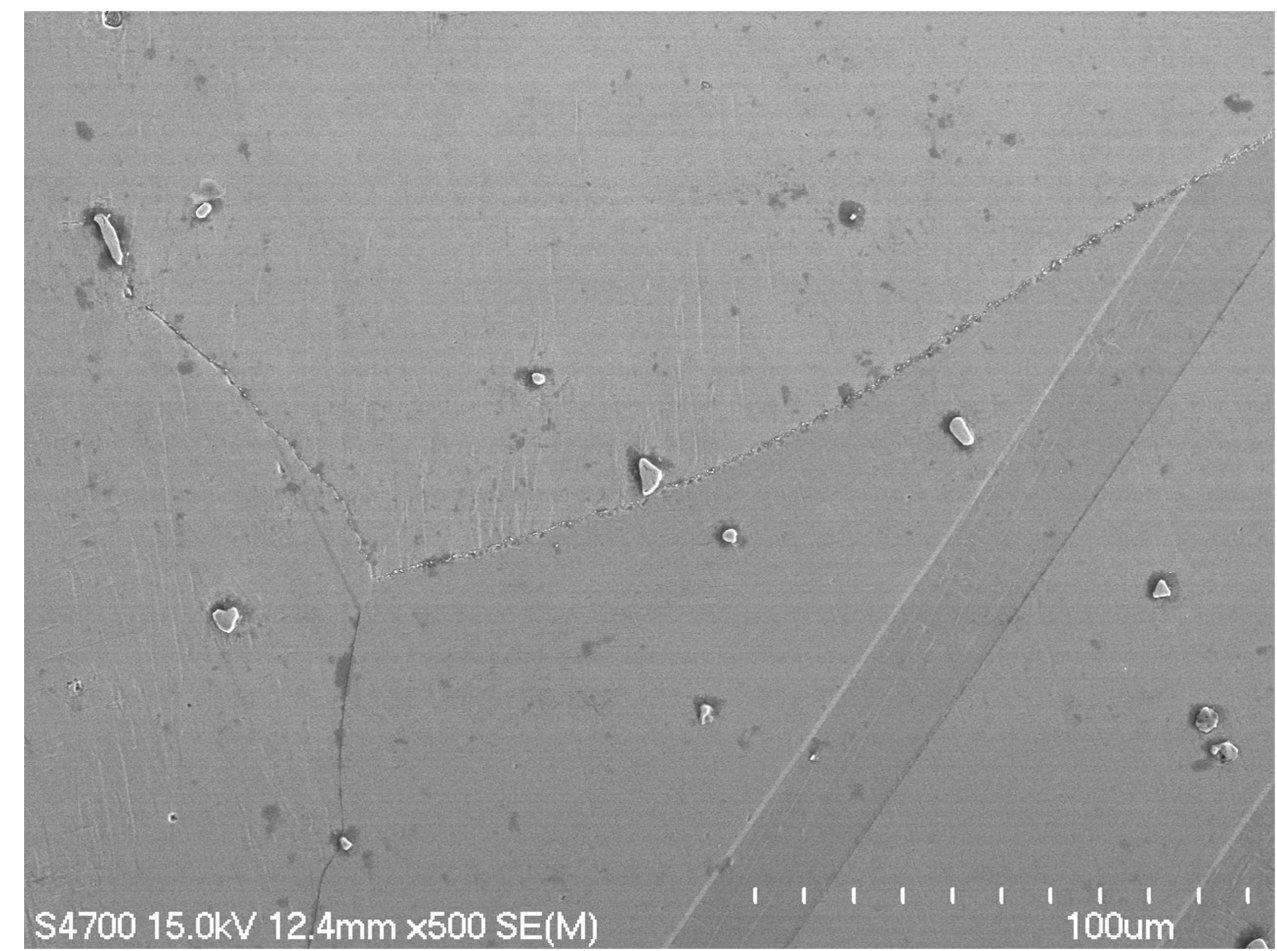

Figure 7. SEM image of Inconel 718 after full heat treatment - the blocky precipitates are MC-carbides.
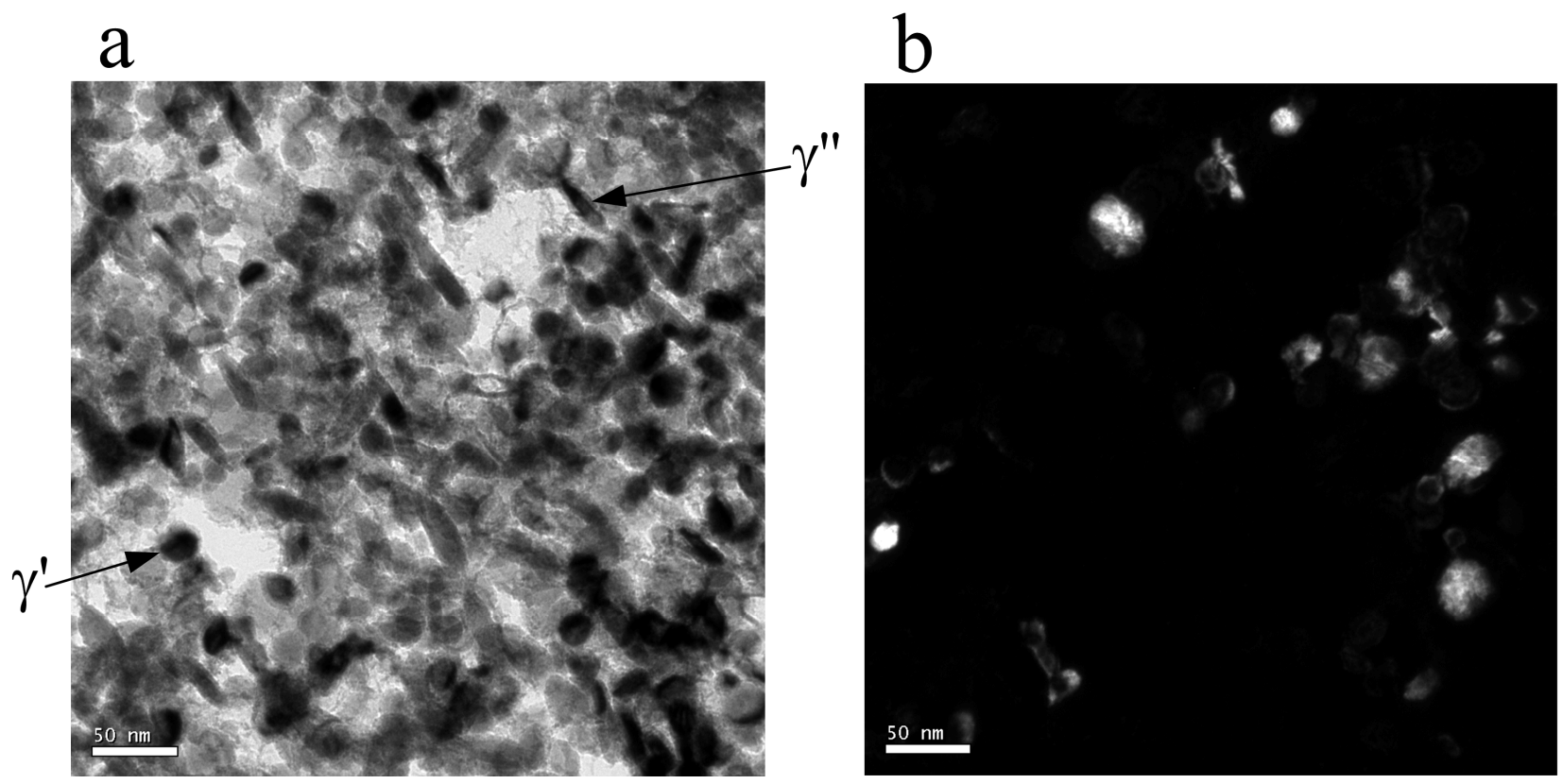

Figure 8. TEM images of $\gamma^{\prime}$ and $\gamma^{\prime \prime}$ phases of Inconel 718, (a) bright field, (b) dark field. 


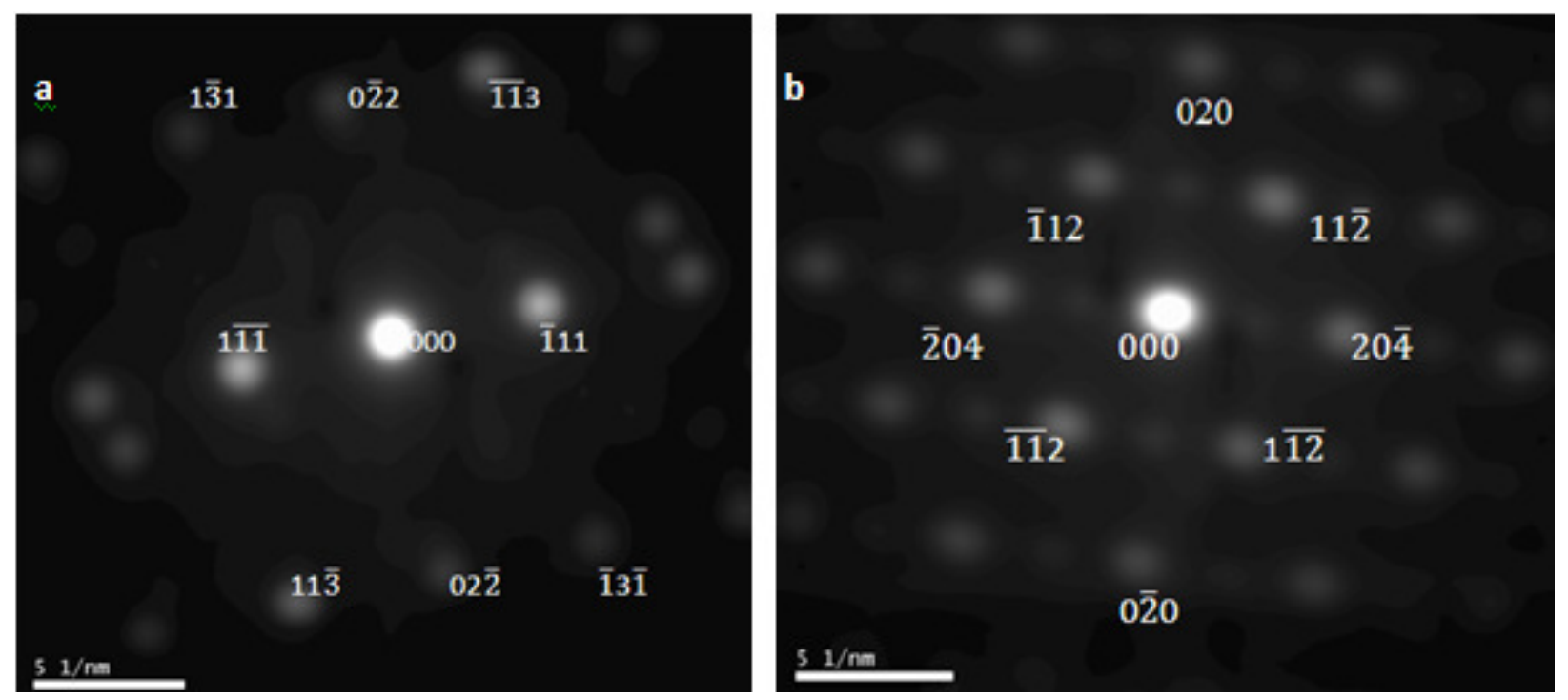

Figure 9. The SAD patterns taken from (a) [211] $\gamma^{\prime}$ zone axes and (b) $[201] \gamma^{\prime \prime}$ zone axes.

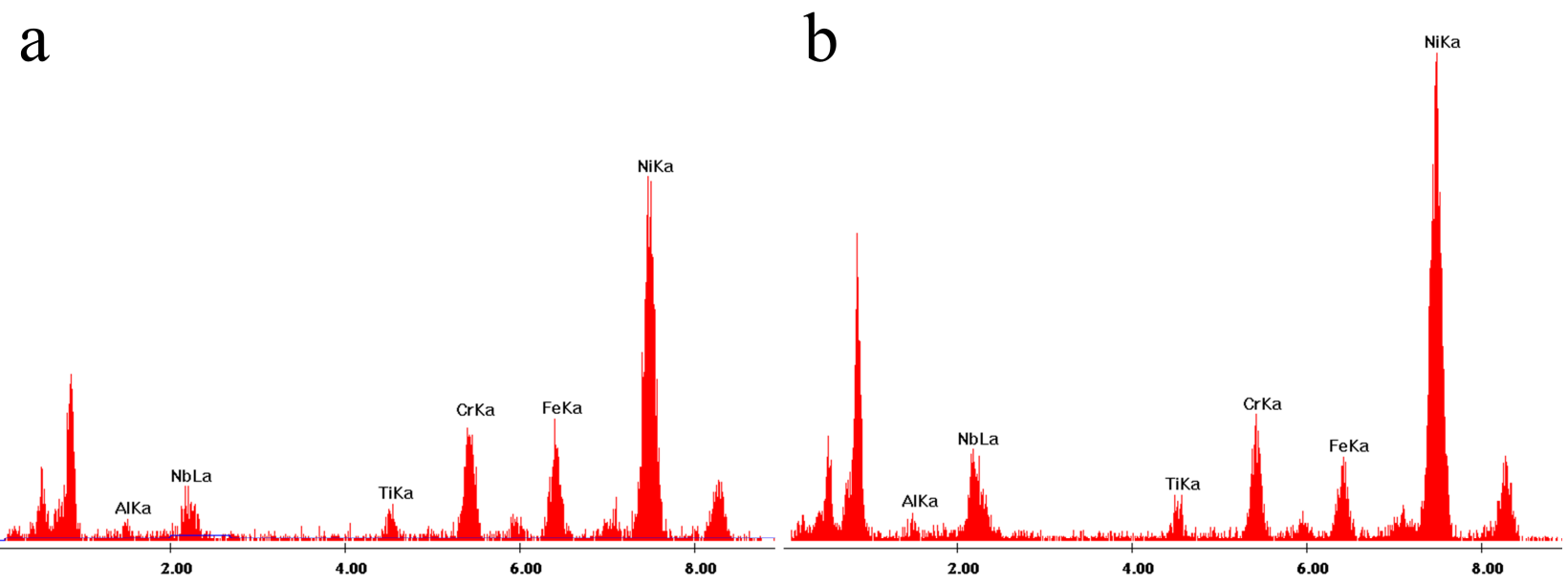

Figure 10. TEM EDS spectra analyses of (a) $\gamma^{\prime}$ phase and (b) $\gamma^{\prime \prime}$ phase.

After aging at $720^{\circ} \mathrm{C}$ for $8 \mathrm{~h}$ both $\gamma^{\prime}$ and $\gamma^{\prime \prime}$ are growing; the mean long-axis of $\gamma^{\prime \prime}$ particle is 40 $\mathrm{nm}$ and the mean short-axis is $14 \mathrm{~nm}$; whereas, the average diameter of the spherical $\gamma^{\prime}$ particle is $17 \mathrm{~nm}$. However, at the aging step at $620^{\circ} \mathrm{C}, \gamma^{\prime \prime}$ stops to grow but $\gamma^{\prime}$ continue to grow and the diameter increases to $21 \mathrm{~nm}$. Comparison of the average size between $\gamma^{\prime}$ and $\gamma^{\prime \prime}$ after aging at 720 ${ }^{\circ} \mathrm{C}$ for $8 \mathrm{~h}$ and after full aging treatment is shown in Figure 11.

If the double-aging treatment of the standard heat treatment scheme is altered to $620^{\circ} \mathrm{C}$ for $16 \mathrm{~h}$ without $720{ }^{\circ} \mathrm{C}$ step, neither $\gamma^{\prime}$ nor $\gamma^{\prime \prime}$ precipitates as indicated in Figure 12. However, with longer aging time, $100 \mathrm{~h}$, at $620^{\circ} \mathrm{C}, \gamma^{\prime}$ will precipitate as shown in Figure 13. 


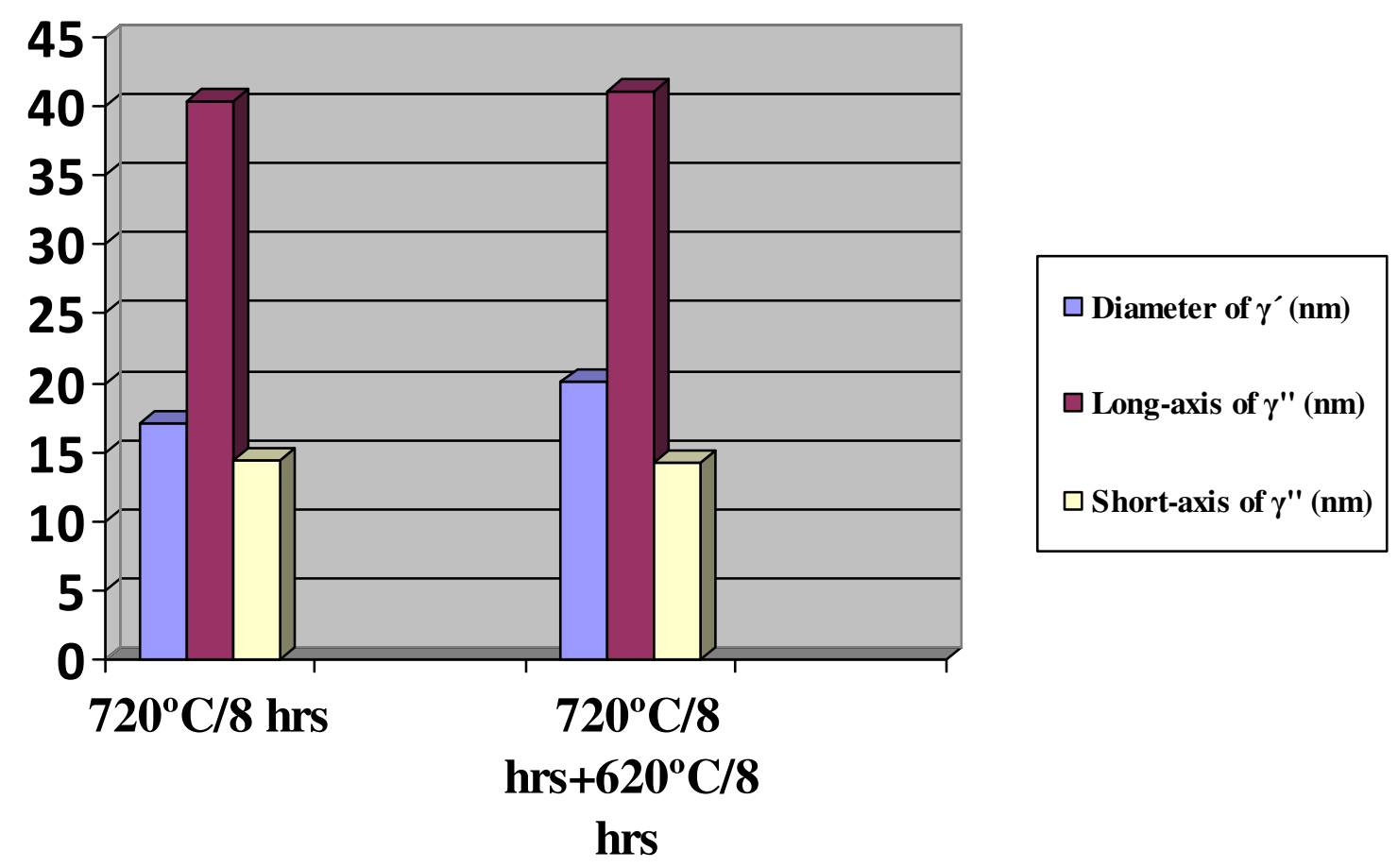

Figure11. Comparison of the average size between $\gamma^{\prime}$ and $\gamma^{\prime \prime}$ after the first step aging at $720{ }^{\circ} \mathrm{C} / 8 \mathrm{hrs}$ and after full double-aging 720 ${ }^{\circ} \mathrm{C} / 8 \mathrm{hrs}+620^{\circ} \mathrm{C} / 8 \mathrm{hrs}$.
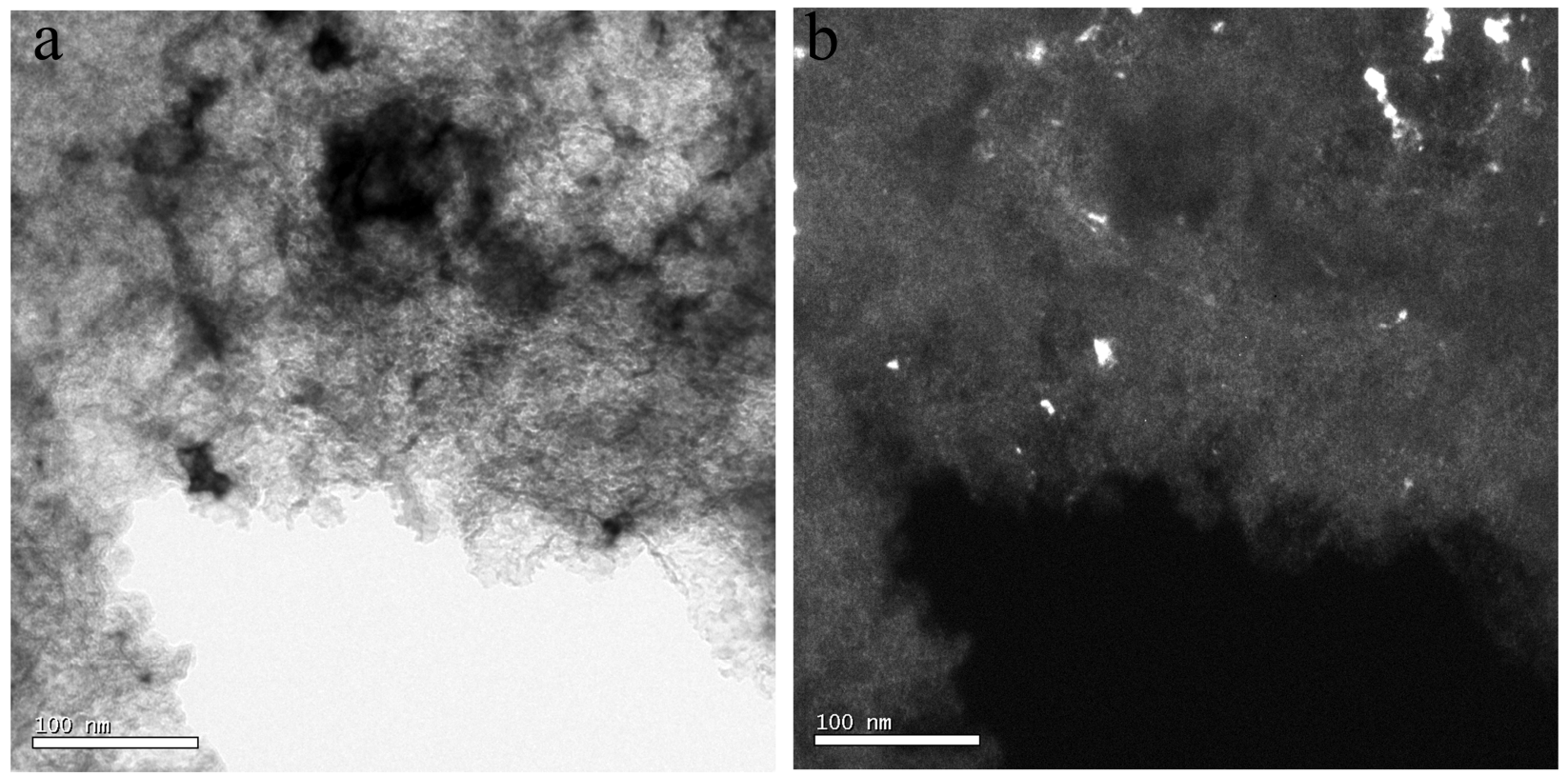

Figure 12. TEM (a) bright-field, (b) dark-field images of Inconel 718 after $620^{\circ} \mathrm{C}$ for $16 \mathrm{~h}$ without the initial aging at $720^{\circ} \mathrm{C}$ step, no $\gamma^{\prime}$ and $\gamma^{\prime \prime}$ are found. 

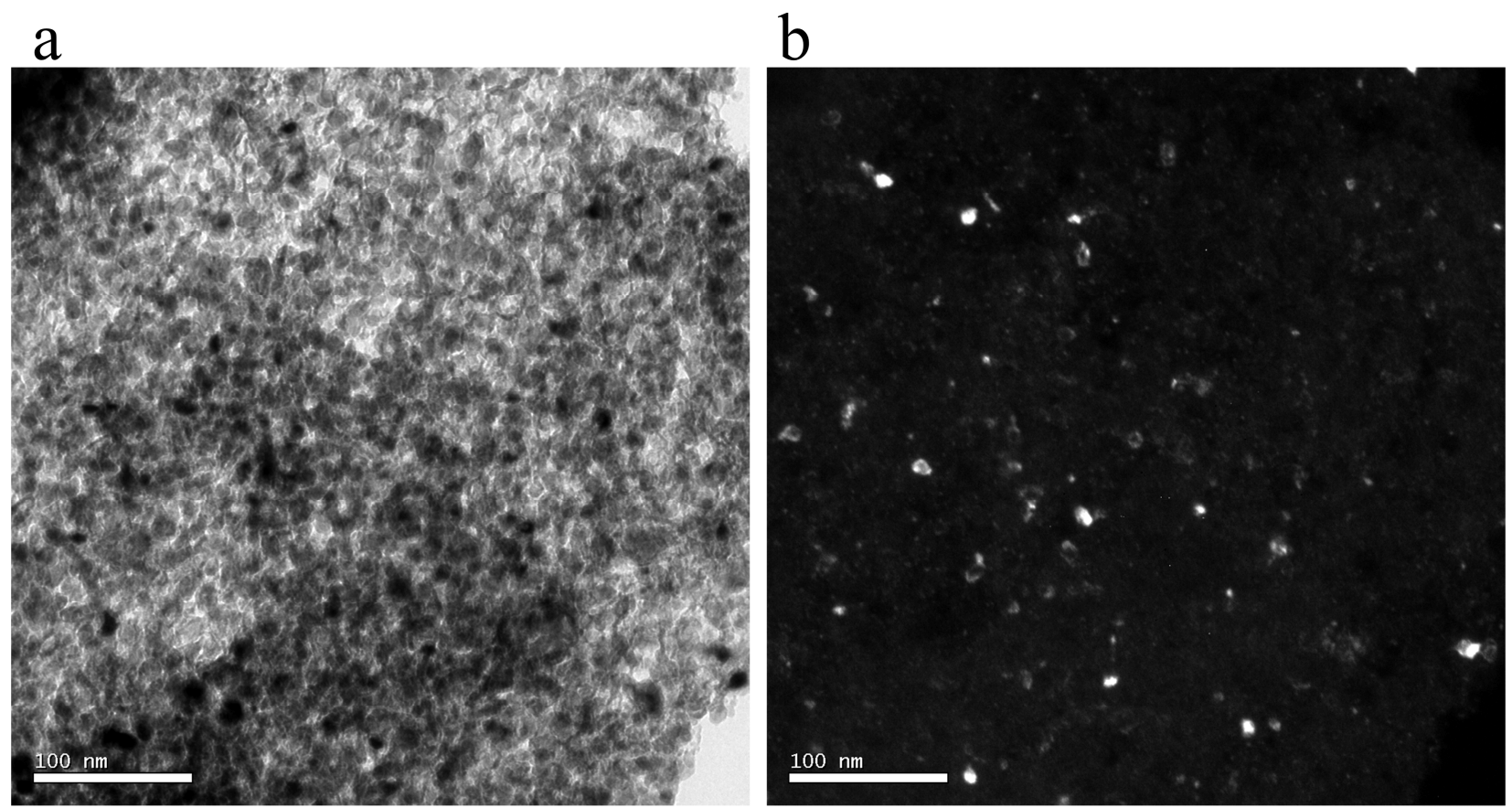

Figure 13. TEM (a) bright-field, (b) dark-field images of Inconel

718 after $620^{\circ} \mathrm{C}$ for $100 \mathrm{~h}$ without $720^{\circ} \mathrm{C}$ step, only $\gamma^{\prime}$ is found.

\section{Conclusions}

The Inconel 718 alloy is mainly strengthened by $\gamma^{\prime}$ and $\gamma^{\prime \prime}$ phases precipitation. The important results of this study can be concluded as follows:

1. After aging treatment, the spherical precipitates observed inside the grains were identified as $\gamma^{\prime}$ phase and the disc shaped precipitates as $\gamma^{\prime \prime}$.

2. At aging $720^{\circ} \mathrm{C}$ for $8 \mathrm{~h}$ both $\gamma^{\prime}$ and $\gamma^{\prime \prime}$ were precipitated; the mean long-axis of $\gamma^{\prime \prime}$ is $40 \mathrm{~nm}$ and the mean short-axis is $14 \mathrm{~nm}$; whereas, the average diameter of the spherical $\gamma^{\prime}$ particle is $17 \mathrm{~nm}$.

3. At the second subsequent $620^{\circ} \mathrm{C}$ ageing step $\gamma^{\prime \prime}$ does not grow but $\gamma^{\prime}$ continue to grow and the diameter increases to $21 \mathrm{~nm}$.

4. In the $\gamma^{\prime} \mathrm{Ni}_{3} \mathrm{Al}$ FCC structure $\mathrm{Ti}$ and some $\mathrm{Nb}$ substitute for $\mathrm{Al}$.

5. In the $\gamma^{\prime \prime} \mathrm{Ni}_{3} \mathrm{Nb} \mathrm{BCT}$ structure $\mathrm{Al}$ and $\mathrm{Ti}$ substitute for $\mathrm{Nb}$ to a minor extent.

\section{Acknowledgements}

This work was supported by National Science Council of Taiwan under grant number NSC 982623-E-214-002-D. SEM and TEM were conducted at MANA-Laboratory of Department of Materials Science and Engineering, I-Shou University. Valuable review comments from Prof. Göran Sjöberg at Volvo Aero Corporation, Sweden are very much appreciated.

\section{References}

1. Chester T. Sims and William C. Hagel, eds., The Superalloys (New York, NY: John Wiley \& Sons, 1972). 
2. Chester T. Sims, Norman S. Stoloff, and William C. Hangel, eds., Superalloys II (New York, NY: John Wiley \& Sons, 1987).

3. Matthew J. Donachie and Stephen J. Donachie, Superalloys: A Technical Guide, second edition (Materials Park, OH: ASM International, 2002).

4. D.A. DeAntonio, D. Duhl, T. Howson, and M.F. Rothman, "Heat Treating of Superalloys," ASM Handbook, vol. 4, Heat Treating (Materials Park, OH: ASM International, 1991), 793-814.

5. A.K. Koul, P. Au, N. Bellinger, R. Thamburaj, W. Wallace and J.P. Immarigeon, "Development of a Damage Tolerant Microstructure for Inconel 718 Turbine Disc Materials," Superalloys 1988, ed. S. Reichman, D.N. Duhl, G. Maurer, S. Antolovich , C. Lund (Warrendale, PA: The Metallurgical Society, 1988), 3-12.

6. R.G. Carlson and J.F. Radavich, "Microstructural Characterization of Cast 718," Superalloy 718-Metallurgy and Applications, ed. E.A. Loria (Warrendale, PA: TMS, 1989), 79-95.

7. G.D. Smith and S.J. Patel, "The Role of Niobium in Wrought Precipitation-Hardened Nickel-base Alloys," Superalloy 718, 625, 706 and Derivatives 2005, ed. E.A. Loria (Warrendale, PA: TMS, 2005), 135-154.

8. W.R. Sun, H.R. Guan, M. Wang, Z.G. Wang, L.F. Huang and Z.Q. Hu, "Influence of Phosphorus on Deformation Mechanism and Mechanical Properties of IN718 Alloy," Superalloy 718, 625, 706 and Derivatives 2005, ed. E.A. Loria (Warrendale, PA: TMS, 2005), 399-407.

9. C.-M. Kuo, Y.-T. Yang, H.-Y. Bor, C.-N. Wei, C.-C. Tai, "Aging Effects on the Microstructure and Creep Behavior of Inconel 718 Superalloy," Materials Science and Engineering A, 510-511 (2009), 289-294. 